\title{
Sources contributing to background surface ozone in the US Intermountain West
}

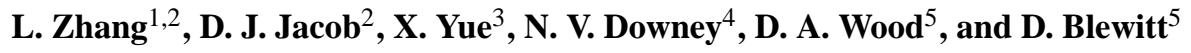 \\ ${ }^{1}$ Laboratory for Climate and Ocean-Atmosphere Sciences, Department of Atmospheric and Oceanic Sciences, School of \\ Physics, Peking University, Beijing, China \\ ${ }^{2}$ School of Engineering and Applied Sciences, Harvard University, Cambridge, Massachusetts, USA \\ ${ }^{3}$ School of Forestry and Environmental Studies, Yale University, New Haven, Connecticut, USA \\ ${ }^{4}$ Earth System Sciences, LLC, Houston, Texas, USA \\ ${ }^{5}$ BP America Production Company, Houston, Texas, USA
}

Correspondence to: L. Zhang (zhanglg@pku.edu.cn)

Received: 15 August 2013 - Published in Atmos. Chem. Phys. Discuss.: 8 October 2013

Revised: 21 February 2014 - Accepted: 11 April 2014 - Published: 2 June 2014

\begin{abstract}
We quantify the sources contributing to background surface ozone concentrations in the US Intermountain West by using the GEOS-Chem chemical transport model with $1 / 2^{\circ} \times 2 / 3^{\circ}$ horizontal resolution to interpret the Clean Air Status and Trends Network (CASTNet) ozone monitoring data for 2006-2008. We isolate contributions from lightning, wildfires, the stratosphere, and California pollution. Lightning emissions are constrained by observations and wildfire emissions are estimated from daily fire reports. We find that lightning increases mean surface ozone in summer by $10 \mathrm{ppbv}$ in the Intermountain West, with moderate variability. Wildfire plumes generate high-ozone events in excess of 80 ppbv in GEOS-Chem, but CASTNet ozone observations in the Intermountain West show no enhancements during these events nor do they show evidence of regional fire influence. Models may overestimate ozone production in fresh fire plumes because of inadequate chemistry and gridscale resolution. The highest ozone concentrations observed in the Intermountain West (>75 ppbv) in spring are associated with stratospheric intrusions. The model captures the timing of these intrusions but not their magnitude, reflecting numerical diffusion intrinsic to Eulerian models. This can be corrected statistically through a relationship between model bias and the model-diagnosed magnitude of stratospheric influence; with this correction, models may still be useful to forecast and interpret high-ozone events from stratospheric intrusions. We show that discrepancy between models in diagnosing stratospheric influence is due in part to differences
\end{abstract}

in definition, i.e., whether stratospheric ozone is diagnosed as produced in the stratosphere (GEOS-Chem definition) or as transported from above the tropopause. The latter definition can double the diagnosed stratospheric influence in surface air by labeling as "stratospheric" any ozone produced in the troposphere and temporarily transported to the stratosphere. California pollution influence in the Intermountain West frequently exceeds $10 \mathrm{ppbv}$ but is generally not correlated with the highest ozone events.

\section{Introduction}

Ozone in surface air is of environmental concern for human health and vegetation (US EPA, 2006). Ozone is formed in the troposphere by photochemical oxidation of $\mathrm{CO}$ and volatile organic compounds (VOCs) in the presence of nitrogen oxides $\left(\mathrm{NO}_{\mathrm{x}} \equiv \mathrm{NO}+\mathrm{NO}_{2}\right)$. It is also transported from the stratosphere. Average ozone concentrations in the free troposphere over western North America are typically 50-70 ppbv (Thompson et al., 2007; Zhang et al., 2010) and are increasing at a rate of $0.41 \pm 0.27 \mathrm{ppbv} \mathrm{yr}^{-1}$ (Cooper et al., 2012). Subsidence of this high-ozone air from the free troposphere to the surface could cause surface ozone concentrations to approach the US National Ambient Air Quality Standard (NAAQS) for ozone of $75 \mathrm{ppbv}$. The US Environmental Protection Agency (EPA) has established the ozone NAAQS as the annual fourth-highest daily maximum 
$8 \mathrm{~h}$ average (MDA8) concentration averaged over three years and is considering a revision of the standard to a value in the range of 60-70 ppbv (US EPA, 2010). As the NAAQS gets closer to background ozone concentrations in the free troposphere, there is increasing concern that it may not be achievable by domestic emission controls.

Background ozone is generally taken to represent the concentration of ozone in the absence of local or regional anthropogenic influences. EPA defines the North American background more precisely as the surface ozone concentration that would be present over the US in the absence of North American anthropogenic emissions (US EPA, 2006). It is an important quantity for policy as it represents a floor below which air quality cannot be improved by eliminating emissions in the US, Canada, and Mexico. The North American background is not an observable quantity and must therefore be estimated from models (McDonald-Buller et al., 2011). A number of studies have been conducted for this purpose, based on the GEOS-Chem global chemical transport model (CTM) (Fiore et al., 2003; Wang et al., 2009; Zhang et al., 2011) and the CAMx regional model with GEOS-Chem boundary conditions (Emery et al., 2012). These studies have shown that the Intermountain West, extending between the Sierra Nevada/Cascades to the west and the Rocky Mountains in the east, is particularly prone to high background ozone due to high elevation, arid terrain, and large-scale subsidence (Fiore et al., 2002; Zhang et al., 2011).

Understanding the natural sources contributing to elevated ozone in the Intermountain West is of crucial importance for policy. There are large differences between models in the contributions from wildfires (Emery et al., 2012; Mueller and Mallard, 2011; Zhang et al., 2011; Jaffe and Wigder, 2012; Singh et al., 2012) and the stratosphere (Lin et al., 2012). Observations are crucial for testing the models and gaining insights into processes. Langford et al. (2009) showed that stratospheric intrusions could cause observed exceedances of the NAAQS at a high-elevation site in Colorado. Measurements in wildfire plumes show highly variable ozone production, ranging from negative to positive (Jaffe and Wigder, 2012; Wigder et al., 2013). Jaffe et al. (2008) argued from analysis of surface ozone observations that wildfires could increase mean surface ozone in the western US by 4 ppbv in a normal fire year and $9 \mathrm{ppbv}$ in a high fire year. Singh et al. (2010) found from aircraft data that fire plumes produce significant ozone only when mixed with urban pollution.

In Zhang et al. (2011), we presented three-year statistics (2006-2008) of background ozone concentrations over the US using the GEOS-Chem global 3-D model with $1 / 2^{\circ} \times 2 / 3^{\circ}$ horizontal resolution over North America. We evaluated the model with surface ozone observations throughout the contiguous US including in the Intermountain West. The model reproduced the frequency distributions of ozone concentrations without bias up to $70 \mathrm{ppbv}$, but could not reproduce exceptional high-ozone events. The CAMx regional model with higher resolution also found underes- timates of these events (Emery et al., 2012). Exceptional events of background origin presumably reflect the longrange transport of fine lamina (Newell et al., 1999). Describing such fine-layered structures in Eulerian models is compromised by stretched-flow numerical diffusion in a manner that cannot be readily fixed by simply increasing the resolution of the model (Rastigejev et al., 2010).

Here we use the model of Zhang et al. (2011) with improved representations of lightning and wildfires to examine the different factors contributing to the ozone background over the Intermountain West, exploiting constraints from observations and identifying model limitations. We also examine the transport of ozone pollution from California to the Intermountain West as a potential complication to background source attribution.

\section{Model description}

We use the GEOS-Chem 3-D global model of atmospheric composition (version 8-02-03; http://geos-chem.org) driven by GEOS-5 assimilated meteorological fields from the NASA Global Modeling and Assimilation Office (GMAO). The GEOS- 5 data have a temporal resolution of $6 \mathrm{~h}(3 \mathrm{~h}$ for surface variables and mixing depths) and a horizontal resolution of $1 / 2^{\circ}$ latitude by $2 / 3^{\circ}$ longitude. We use a nested version of GEOS-Chem (Chen et al., 2009) with the native $1 / 2^{\circ} \times 2 / 3^{\circ}$ horizontal resolution over North America and adjacent oceans $\left(140-40^{\circ} \mathrm{W}, 10-70^{\circ} \mathrm{N}\right)$ and $2^{\circ} \times 2.5^{\circ}$ horizontal resolution over the rest of the world. A detailed description of the model and its emission inventories is given in Zhang et al. (2011). Zhang et al. (2012) used the same model in a source attribution study of nitrogen deposition over the United States. Here we improve the model by using lightning data from the National Lightning Detection Network (NLDN) and daily wildfire emissions, as described below.

We conduct three-year (2006-2008) GEOS-Chem model simulations. For all simulations, we first conduct a global GEOS-Chem simulation at $2^{\circ} \times 2.5^{\circ}$ horizontal resolution and then use the output archived at $3 \mathrm{~h}$ temporal resolution as dynamic boundary conditions for the nested model at $1 / 2^{\circ} \times 2 / 3^{\circ}$ resolution. A six-month initialization is used in all cases. Zhang et al. (2011) evaluated the simulation with ozone data from the Clean Air Status and Trends Network (CASTNet) monitoring sites across the US. Here our focus will be on the Intermountain West.

\subsection{Lightning $\mathrm{NO}_{\mathrm{x}}$ emissions}

The standard representation of lightning $\mathrm{NO}_{\mathrm{x}}$ emissions in GEOS-Chem (Sauvage et al., 2007; Murray et al., 2012) uses a monthly climatology of $10 \mathrm{yr}$ averaged satellite lightning observations from the Optical Transient Detector (OTD) and the Lightning Imaging Sensor (LIS) coupled to the model deep convection. $\mathrm{NO}_{\mathrm{x}}$ yields per flash are $260 \mathrm{~mol}$ 
in the tropics and $500 \mathrm{~mol}$ in the extratropics (Huntrieser et al., 2007, 2008; Hudman et al., 2007; Ott et al., 2010), with a fairly arbitrary boundary between the two at $23^{\circ} \mathrm{N}$ in North America and $35^{\circ} \mathrm{N}$ in Eurasia. In this work we use the higher-density NLDN data for the US to constrain model flash rates for individual years. The NLDN observes cloudto-ground lightning flashes only, and intra-cloud flashes are estimated to be three times that amount (Boccippio et al., 2001). We also move the boundary for extratropical vs. tropical $\mathrm{NO}_{\mathrm{x}}$ yields per flash from $23^{\circ} \mathrm{N}$ to $32^{\circ} \mathrm{N}$ in order to correct for excessive ozone previously generated over the southwest US in summer by lightning in the Mexican Cordillera (Zhang et al., 2011). The vertical distribution of lightning $\mathrm{NO}_{\mathrm{x}}$ release follows Ott et al. (2010) with the bulk released in the detraining air at the top of the convective column and only $1-7 \%$ released below $2 \mathrm{~km}$.

Figure 1 shows the spatial distribution of summer 2006-2008 lightning $\mathrm{NO}_{\mathrm{x}}$ emissions and compares it to that used in Zhang et al. (2011). There are large regional differences. Our mean value for the contiguous US is $32 \%$ lower. This reflects a $24 \%$ reduction in flash rates and an $8 \%$ reduction in the $\mathrm{NO}_{\mathrm{x}}$ yield per flash (due to moving the tropical/extratropical boundary for $\mathrm{NO}_{\mathrm{x}}$ yields as described above). Hudman et al. (2007) found that a US lightning $\mathrm{NO}_{\mathrm{x}}$ source of $0.17 \mathrm{Tg} \mathrm{N}$ for 1 July-15 August 2004 could reproduce the upper tropospheric $\mathrm{NO}_{\mathrm{x}}$ measurements from the International Consortium on Atmospheric Transport and Transformation (ICARTT) aircraft campaign (Bertram et al., 2007). Our work gives a consistent US lightning $\mathrm{NO}_{\mathrm{x}}$ source of $0.18 \mathrm{Tg} \mathrm{N}$ for the same period of 2006-2008.

\subsection{Wildfire emissions}

Zhang et al. (2011) used the Global Fire Emission Database version 2 (GFED2) fire emission inventory (van der Werf et al., 2006) with $1^{\circ} \times 1^{\circ}$ horizontal resolution and monthly temporal resolution. Here we apply a daily wildfire emission inventory at the same spatial resolution developed by Yue et al. (2013) for the western US $\left(31-49^{\circ} \mathrm{N}, 101-125^{\circ} \mathrm{W}\right)$. This inventory uses the inter-agency fire reports from the national Fire and Aviation Management Web application system (FAMWEB, https://fam.nwcg.gov/fam-web/). Each report includes the name, start and end date, location, area burned, and cause for the fire (Westerling et al., 2006). The reported areas burned are aggregated onto the $1^{\circ} \times 1^{\circ}$ grid, and a daily scaling factor over the duration of each fire is applied on the basis of local temperature, precipitation, and relative humidity from meteorological reanalyses (Yue et al., 2013). Fuel consumption rates are taken from GFED2, and the emission factors of gases and aerosols are from Andreae and Merlet (2001) as in GFED2.

Figure 2 shows the spatial and temporal distributions of carbon burned over the Intermountain West in 2006-2008. There is large interannual variability in the magnitude and location of the fires. 2007 was a particularly high fire year,
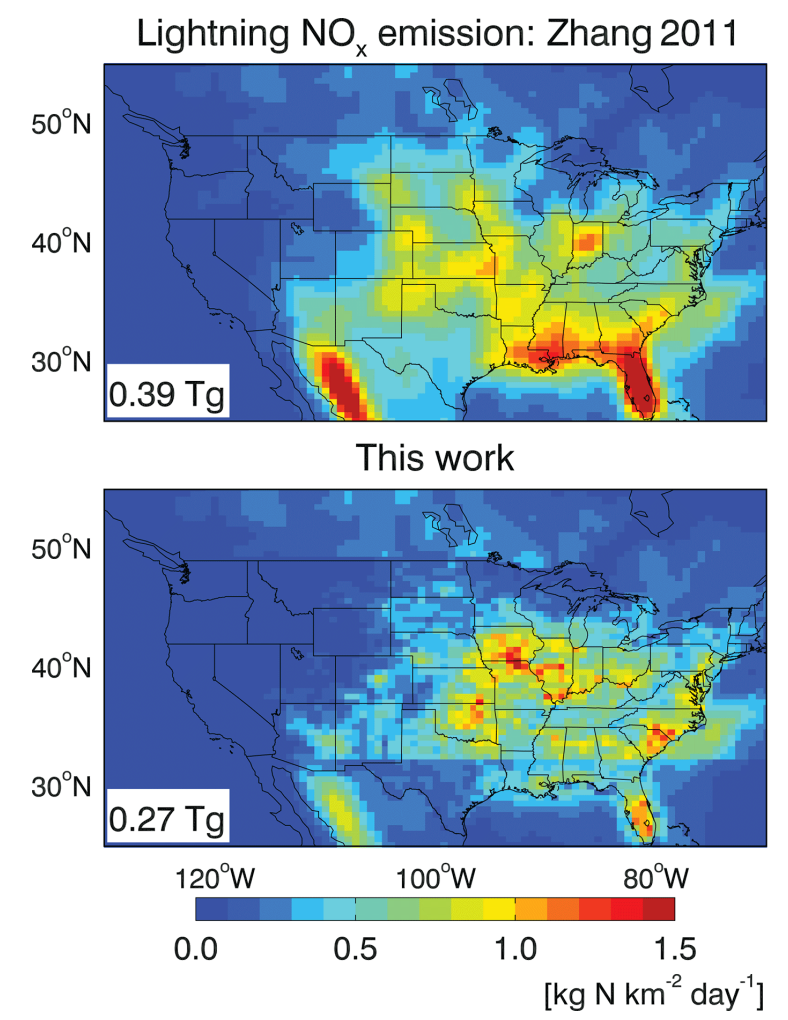

Figure 1. Mean $\mathrm{NO}_{\mathrm{x}}$ emissions from lightning in summer (JuneAugust) 2006-2008. Values from Zhang et al. (2011) are compared to the improved simulation in this work. The numbers inset indicate the mean summer total lightning emissions $(\operatorname{Tg} N)$ over the contiguous US.

2006 moderately high, and 2008 low. Large fires occurred over Idaho in 2007. The GFED2 emissions are on average $30 \%$ lower than those derived from fire reports. There is also a large daily variability not captured by the monthly emissions. GFED2 uses area-burned products from the Moderate Resolution Imaging Spectroradiometer (MODIS) satellite instrument at $500 \mathrm{~m}$ resolution (van der Werf et al., 2006) and thus generally misses small fires with the areas burned smaller than 25 ha, but those small fires account for only $0.6 \%$ of the total areas burned in the fire reports for summer 2006-2008. The difference between GFED2 and fire reports is thus mainly due to relatively large fires.

\subsection{Stratospheric ozone}

Representation of stratospheric ozone is unchanged from Zhang et al. (2011). Stratospheric ozone is simulated with the Linoz linearized parameterization (McLinden et al., 2000) above the tropopause diagnosed by the GEOS-5 data and transported to the troposphere with the model winds. The resulting global cross-tropopause ozone flux is $490 \mathrm{Tg}$ ozone $\mathrm{a}^{-1}$, consistent with the range of $475 \pm 120 \mathrm{Tg} \mathrm{a}^{-1}$ constrained by observations (McLinden et al., 2000). Barrett et al. (2012) tested vertical transport 

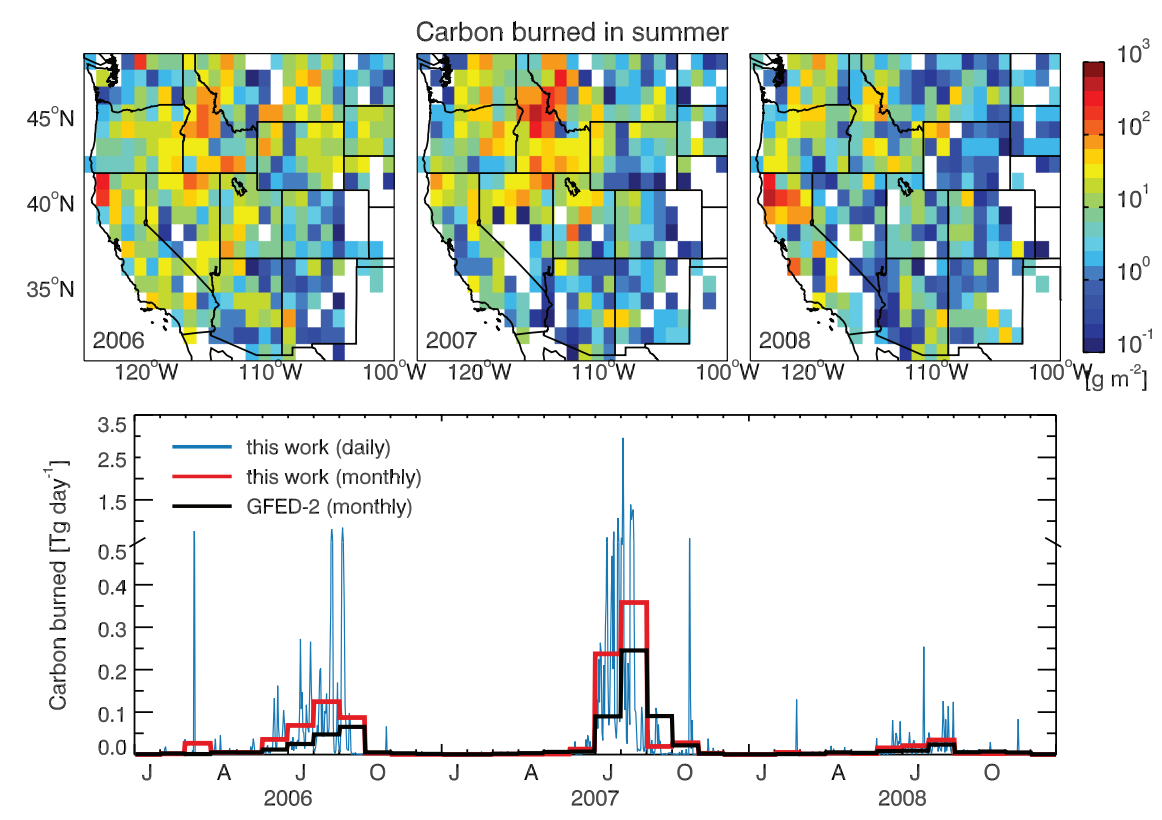

Figure 2. Wildfire emissions in the western US. The top panels show the spatial distribution of carbon burned in summer (JJA) 2006-2008 from Yue et al. (2013) as described in the text. The bottom panel shows the daily time series of wildfire emissions over the Intermountain West $\left(120-100^{\circ} \mathrm{W}, 31-49^{\circ} \mathrm{N}\right)$ in 2006-2008. Also shown are the monthly GFED2 inventory used by Zhang et al. (2011) (black line) and the monthly means from the Yue et al. (2013) inventory. Note the break in the ordinate scale. The $x$ axis labels represent January (J), April (A), July (J), and October (O).

in GEOS-Chem with GEOS-5 meteorological data and the same model transport configuration using observations of beryllium-7 $\left({ }^{7} \mathrm{Be}\right)$, a cosmogenic tracer produced in the upper troposphere/lower stratosphere (UT/LS). They showed that GEOS-Chem successfully simulates the ${ }^{7} \mathrm{Be}$ observations and their latitudinal gradients both in the UT/LS and in surface air. This supports the simulation of vertical transport in GEOS-Chem. Figure 3 compares model results to 2006 ozonesonde data from Ozonesonde Network Study 2006 (IONS-06) (Thompson et al., 2008; http://croc.gsfc.nasa.gov/ intexb/ions06.html) in the western US. There is no overall bias although the model gradient over Trinidad Head (California) is weaker than observed.

Lin et al. (2012) using the AM3 model found much larger stratospheric influences on surface ozone in the western US than the GEOS-Chem estimates of Zhang et al. (2011). However, they defined stratospheric influence differently. Zhang et al. (2011) defined as stratospheric any ozone (or more precisely odd oxygen) produced above the GEOS-5 tropopause, and simulated its transport in the troposphere as a tagged tracer subject to tropospheric loss, following the approach initially proposed by Wang et al. (1998) and used in a number of studies (Li et al., 2002; Fiore et al., 2003; Sudo and Akimoto, 2007; Zhang et al., 2009). Lin et al. (2012) labeled as stratospheric any ozone present above the tropopause (defined as the "e90" surface of Prather et al., 2011). In the Zhang et al. (2011) approach, "stratospheric ozone" is unambiguously produced naturally in the stratosphere by photol-

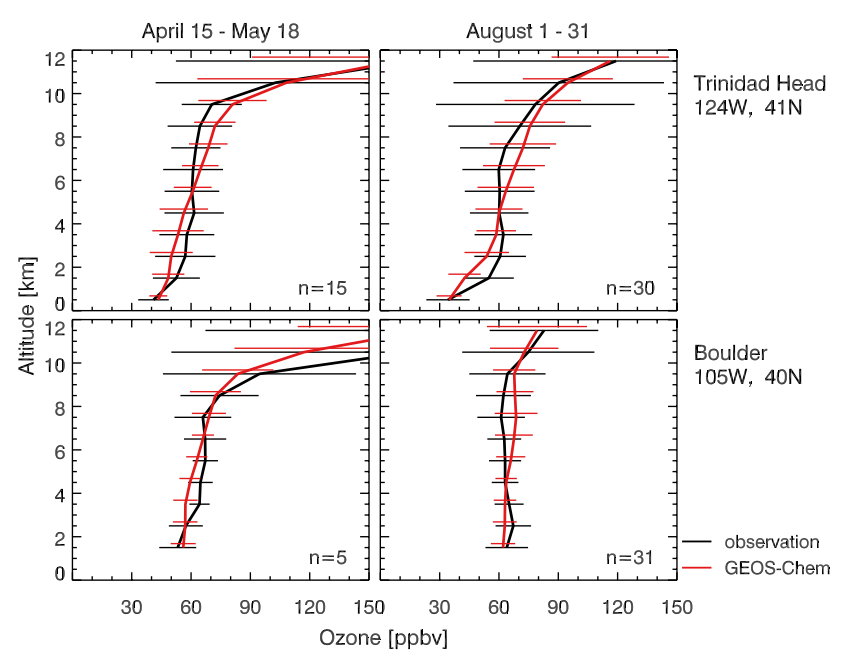

Figure 3. Mean ozone concentration profiles over Trinidad Head, California, (top panels) and Boulder, Colorado (bottom panels). The black lines show the means and standard deviations of ozonesonde data for the period of 15 April-18 May (left) and 1-31 August (right) 2006. The red lines show the corresponding model values. Numbers of profiles are shown inset.

ysis of molecular oxygen. In the Lin et al. (2012) approach, ozone produced in the troposphere and transported above the tropopause would be labeled as "stratospheric ozone". Thus, the Lin et al. (2012) approach diagnoses larger stratospheric 
influence at the surface, in a manner consistent with observations of stratospheric intrusions, but some of their "stratospheric" ozone could actually have been produced in the troposphere including by anthropogenic sources.

In this paper we compare results from the Zhang et al. (2011) and Lin et al. (2012) approaches for diagnosing stratospheric influence, thus quantifying the tropospheric contribution to stratospheric ozone in the latter approach. To implement the Lin et al. (2012) approach, we derive the e90 tropopause in GEOS-Chem following Prather et al. (2011). This is done by simulating in the model an artificial tracer with 90-day e-folding lifetime and globally uniform surface emission such that its global mean whole-atmosphere mixing ratio is $100 \mathrm{ppbv}$. The tropopause is then defined as the concentration isopleth below which $80 \%$ of total air mass resides. By this definition we derive a tropopause of $85 \mathrm{ppbv}$ in GEOS-Chem, which is the same as found by Lin et al. (2012) with AM3. Any ozone present above this tropopause is then labeled as stratospheric, and its transport in the troposphere is described by a tagged tracer subject to tropospheric loss. The tagged ozone tracers describing the Zhang et al. (2011) and Lin et al. (2012) approaches are both initialized for five years in order to equilibrate the relevant stratosphere.

\section{Natural background contributions to surface ozone in the Intermountain West}

Here we compare model results to the ensemble of ozone observations at CASTNet monitoring sites in the western US (Fig. 4) and use this comparison to examine the contributions of different natural sources of ozone (lightning, wildfires, stratosphere). All data shown are MDA8 concentrations since this is the form of the NAAQS.

Figure 5 compares the simulated vs. measured MDA8 ozone concentrations for the ensemble of CASTNet sites in the Intermountain West in spring and summer 2006-2008. The model reproduces the mean concentration and variability with no significant bias for the ensemble of sites $(r=0.63-0.65)$. Previous model comparison with the same CASTNet observations for summer 2006 showed a relatively low correlation ( $r=0.30$; Fig. 3 of Zhang et al., 2011) and high biases of $12 \%$ in the southwest US (Zhang et al., 2011). The summertime comparison in this work $(r=0.65)$ is significantly improved relative to Zhang et al. (2011) due to the modifications to lightning emissions as further discussed below. However, the model still systematically underestimates the observed high-ozone events with $\mathrm{O}_{3}>75 \mathrm{ppbv}(0.4 \%$ of the data in spring, $0.7 \%$ in summer). From correlations with model tracers we find that, in spring, these events are associated with stratospheric intrusions, as discussed below, and in summer with regional anthropogenic pollution. For the observed summertime high-ozone events, the model shows elevated $\mathrm{CO}$ enhancements from North American anthropogenic emissions $(42 \pm 30 \mathrm{ppbv}$; differences in the $\mathrm{CO}$ con-

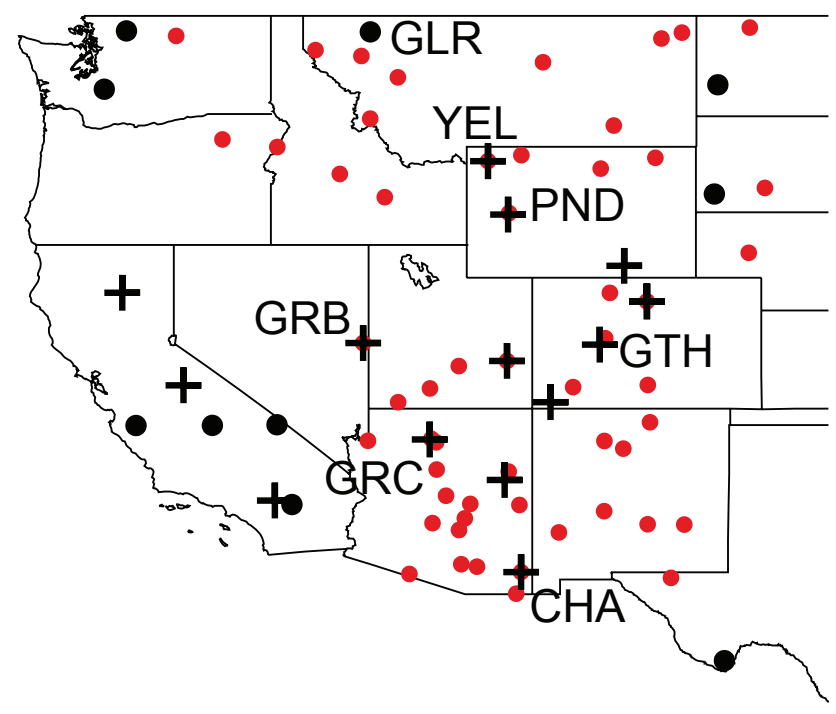

Figure 4. CASTNet ozone monitoring sites (black circles and pluses) in the western US used for 2006-2008 model evaluation. Pluses denote sites above $1.5 \mathrm{~km}$ altitude. Sites discussed in the text are labeled: GLR, Glacier National Park (NP), Montana; YEL, Yellowstone NP, Wyoming; PND, Pinedale, Wyoming; GTH, Gothic, Colorado; GRB, Great Basin NP, Nevada; GRC, Grand Canyon NP, Arizona; CHA, Chiricahua National Monument (NM), Arizona. Also shown are the IMPROVE particulate matter monitoring sites (red circles) in the Intermountain West used for Fig. 9.

centration between the standard simulation and a sensitivity simulation with zero North American anthropogenic emissions), significantly higher than those for the ensemble of data in summer $(21 \pm 14 \mathrm{ppbv} ; p$ value $<0.01$ from the $t$ test).

\subsection{Lightning}

In Fig. 6 we show the time series of measured and simulated MDA8 ozone concentrations at Chiricahua NM and Grand Canyon NP, both in Arizona, in summer 2007. These are the two CASTNet sites most sensitive to lightning in the model. Zhang et al. (2011) overestimated measurements at the two sites, particularly in August. Our improved simulation largely corrects the bias. The correlation coefficients $(r)$ between measurements and model results are also significantly improved: from -0.08 to 0.46 at Chiricahua NM and from 0.23 to 0.47 at Grand Canyon NP. We find that most of the improvements result from use of the NLDN data to constrain the lightning flash rates, with an additional 1-2 ppbv ozone decrease from the reduction of the lightning $\mathrm{NO}_{\mathrm{x}}$ yields over Mexico. Figure 6 also shows the ozone enhancements from lightning as computed by difference between our standard simulation and a sensitivity simulation with lightning $\mathrm{NO}_{\mathrm{x}}$ emissions turned off. Lightning emissions increase ozone concentrations on average by $6.5 \pm 2.6 \mathrm{ppbv}$ at Chiricahua NM and 7.6 $\pm 3.4 \mathrm{ppbv}$ at Grand Canyon NP. 

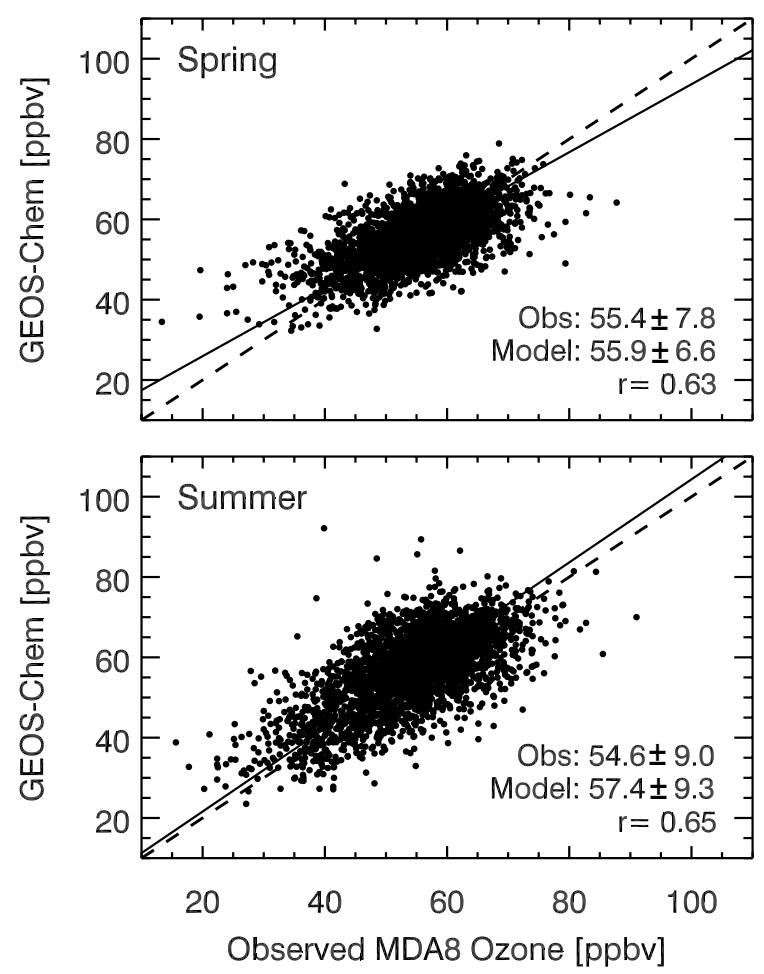

Figure 5. Simulated vs. observed daily maximum $8 \mathrm{~h}$ average (MDA8) ozone concentrations at the ensemble of CASTNet sites in the Intermountain West (Fig. 4) for 2006-2008: spring (MarchMay; top panel) and summer (June-August; bottom panel). Each point represents a daily value for a site in Fig. 4. Also shown are the $1: 1$ line (dashed line) and the reduced-major-axis regression lines (solid lines). The mean concentrations, standard deviations, and correlation coefficients $(r)$ are shown inset.

The maximum lightning influence in the model time series (17.9 ppbv) is associated with a total ozone concentration of $66 \mathrm{ppbv}$. For the model population with total ozone in excess of $65 \mathrm{ppbv}$ the lightning influence averages $6.1 \pm 2.1 \mathrm{ppbv}$ at Chiricahua NM and $7.9 \pm 3.2$ ppbv at Grand Canyon NP, similar to the seasonal averages.

Figure 7a shows the spatial distribution of seasonal mean ozone enhancements from lightning in surface air over the US in summer 2007. Lightning increases ozone on average by $6-8 \mathrm{ppbv}$ in the Intermountain West. The higher lightning ozone enhancements in the west than in the east, despite lower lightning activity (Fig. 1), reflect higher elevation and deeper boundary layer heights that allow more free tropospheric influence. Kaynak et al. (2008) found in the regional CMAQ model that lightning $\mathrm{NO}_{\mathrm{x}}$ emissions increases surface ozone by generally less than 2 ppbv, but their results focused on urban areas particularly in the eastern US.

\subsection{Wildfires}

We compute the ozone enhancements from wildfires in our simulation as the difference to a sensitivity simulation with

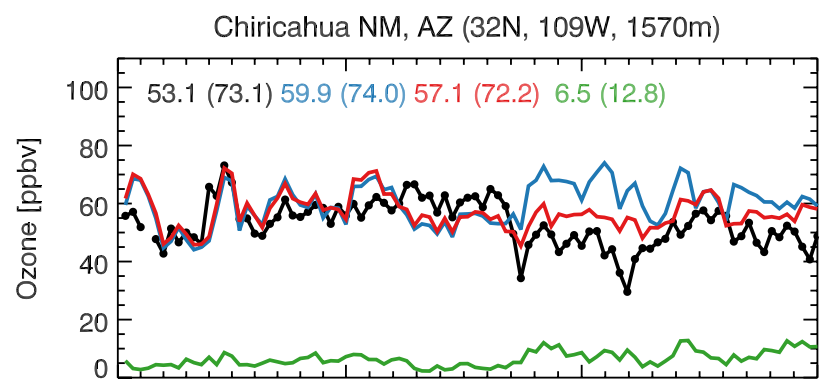

Grand Canyon NP, AZ (36N, 112W, 2073m)

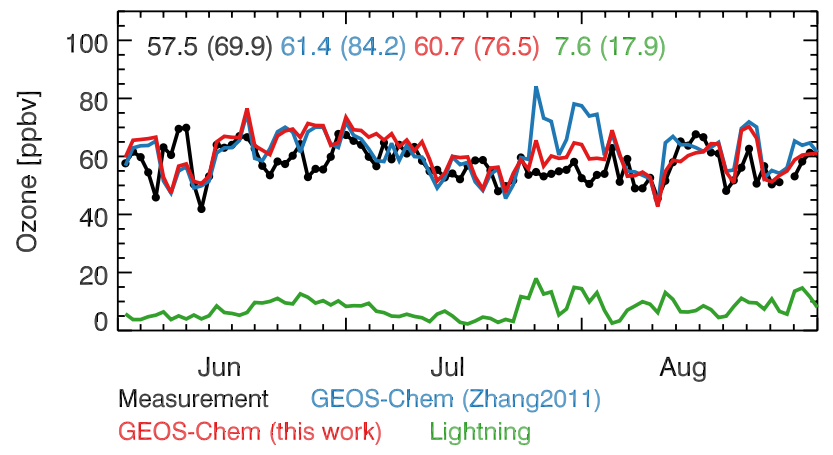

Figure 6. Time series of measured and simulated daily maximum $8 \mathrm{~h}$ average (MDA8) ozone concentrations at Chiricahua NM and Grand Canyon NP (both in Arizona) in summer (June-August) 2007. Measurements (black line) are compared to model results from the Zhang et al. (2011) simulation (blue line) and from this work (red line). Also shown are simulated ozone enhancements from lightning as computed by the difference between our standard simulation and a sensitivity simulation with lightning emissions turned off (green). The mean (maximum) concentrations for the time period are shown inset.

no open fire emissions. Figure $7 \mathrm{~b}$ shows the mean results for summer 2007, when wildfire emissions were particularly high (Fig. 2). In the model, wildfires increase ozone by up to $20 \mathrm{ppbv}$ over the Idaho and Montana burning areas, but the influence decreases rapidly downwind to a background influence of 1-3 ppbv.

Figure 8 shows the time series of measured and simulated MDA8 ozone concentrations at Glacier NP, Montana, and Yellowstone NP, Wyoming, in summer 2007. In the model these show the largest wildfire ozone influences among all CASTNet sites. The model ozone enhancement from wildfires ( $\Delta$ wildfires in Fig. 8 ) is highly episodic, with values as high as $40 \mathrm{ppbv}$, reflecting the daily resolution of emissions. The Zhang et al. (2011) simulation using monthly mean emissions shows similar mean ozone enhancements from wildfires but with much weaker daily structure. The right panels of Fig. 8 show measurements of organic carbon (OC) aerosol at collocated sites of the Interagency Monitoring of Protected Visual Environments (IMPROVE) (http: //vista.cira.colostate.edu/improve/). We can see elevated OC measurements when the model simulates high wildfire ozone 


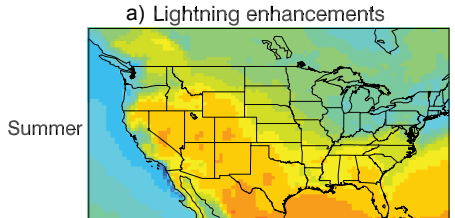

c) Stratosphere (GEOS-Chem definition)

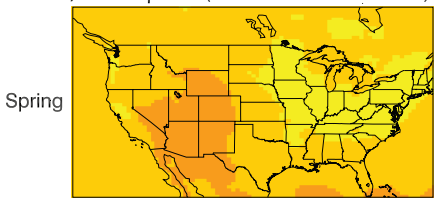

e) California pollution enhancements

Spring

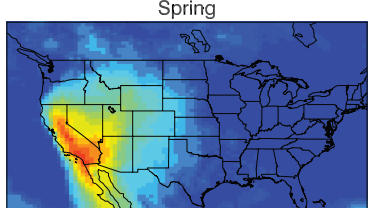

Summer

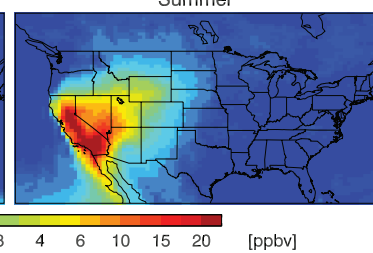

b) Wildfire enhancements

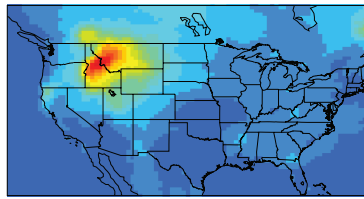

d) Stratosphere (e90 tracer)

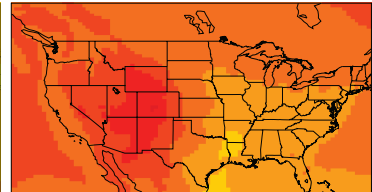

(1)

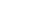

Figure 7. Effects of different sources on seasonal mean MDA8 surface ozone as simulated by GEOS-Chem. Top panels: enhancements from lightning and wildfires for summer (June-August) 2007, as diagnosed by difference with a simulation not including these sources. Middle panels: stratospheric influence in spring (March-May) 2006 estimated by defining stratospheric ozone either as ozone produced above the tropopause (Zhang et al., 2011; left) or ozone transported across the tropopause (Lin et al., 2012; right). Bottom panels: enhancements from California anthropogenic emissions for spring and summer 2006, as diagnosed by difference with a simulation not including these emissions.

enhancements. However, the measurements show no correlated ozone enhancements that would indicate ozone production in the fire plumes. The model is in serious error.

We further examine whether wildfire emissions would lead to regional enhancements of ozone concentrations. Figure 9 correlates daily mean OC aerosol and ozone concentrations in the Intermountain West $\left(120-100^{\circ} \mathrm{W}, 30-50^{\circ} \mathrm{N}\right)$ to fiveday fires (carbon burned) in the region for the summers 2006-2008. OC aerosol concentrations are averages of observations at the IMPROVE sites (http://vista.cira.colostate. edu/improve/). Ozone concentrations are mean MDA8 ozone values averaged over the CASTNet sites. Fires are the dominant source of OC aerosol in the region in summer (Park et al., 2007; Spracklen et al., 2007), as reflected by the strong positive correlation between the two, but no such correlation is found for ozone. CASTNet and IMPROVE sites have different spatial distributions (Fig. 4), so we also examined the correlation for the subset of IMPROVE sites collocated with CASTNet. We find the same positive correlation for OC aerosol as shown in Fig. 9.

Model overestimate of ozone production in fresh fire plumes may result from inadequate chemistry, uncertainties in the emission factor, and coarse grid resolution. Typical fire size recorded in the fire reports ranges from 2 to 50 ha and large fires are over $400-10^{4}$ ha, which is much smaller than the model $1 / 2^{\circ} \times 2 / 3^{\circ}$ horizontal resolution. Ozone production in fire plumes is $\mathrm{NO}_{\mathrm{x}}$-limited because of the VOCrich conditions. Our $\mathrm{NO}_{\mathrm{x}}$ emission factor for wildfires from GFED2 is $3.0 \mathrm{~g}$ NO per kg of dry mass burned. The CMAQ model has a mean emission factor of $2.0 \mathrm{~g} \mathrm{NO}$ per $\mathrm{kg}$ of dry mass burned for the US (Smith and Mueller, 2010) and generates ozone plume enhancements of 30-50 ppbv from wildfires in the west (Mueller and Mallard, 2011), similar to GEOS-Chem. These emission factors may be too high. Akagi et al. (2011) summarized recent emission factor measurements and recommended a mean value for extratropical fires of $1.12 \mathrm{~g} \mathrm{NO}$ per $\mathrm{kg}$ of dry mass burned. However, the $\mathrm{NO}_{\mathrm{x}}$ emission factor varies significantly spatially and temporally depending on the local combustion efficiency (smoldering vs. flaming) and biomass nitrogen load (Jaffe and Wigder, 2012).

Ozone production in fresh plumes is limited by fast conversion of $\mathrm{NO}_{\mathrm{x}}$ to peroxyacetyl nitrate (PAN) (Jacob et al., 1992; Alvarado et al., 2010), but subsequent decomposition of PAN in aged plumes could lead to ozone enhancements far downwind (Jaffe and Wigder, 2012). This effect could be magnified by buoyant plume lofting above the boundary layer, followed by ozone production over an aging time of a few days. There are many observations of elevated ozone in aged fire plumes sampled from aircraft and at mountain sites (Mauzerall et al., 1998; Real et al., 2007; Jaffe and Wigder, 2012). These plumes could then be fumigated to the surface by boundary layer entrainment and cause high ozone in surface air.

We use the standard GEOS-Chem chemical scheme as described by Horowitz et al. (1998), Bey et al. (2001), and Mao et al. (2010) and find little PAN-driven regional production of ozone from fires in GEOS-Chem, as reflected by the small contribution from wildfires to ozone over the scale of the Intermountain West (Fig. 8). A recent study with an improved PAN chemistry also showed that fires in GEOS-Chem make little contribution to PAN at northern mid-latitudes in summer (Fischer et al., 2014). However, this could be because the model does not account for very short-lived VOCs emitted by fires and cannot resolve photochemistry on the scale of the fire plumes. We conducted a sensitivity simulation with the wildfire emission factor for $\mathrm{NO}_{\mathrm{x}}$ reduced by a factor of 3 to $1.0 \mathrm{~g} \mathrm{NO}$ per kg of dry mass burned and with this $\mathrm{NO}_{\mathrm{x}}$ emitted as $40 \% \mathrm{NO}_{\mathrm{x}}, 40 \% \mathrm{PAN}$, and $20 \% \mathrm{HNO}_{3}$ (Alvarado et al., 2010). Results in Fig. 8 show peak ozone concentrations in fire plumes reduced by about a factor of 2 from the standard simulation but still sufficiently large that they should be detectable in the observations, which is not the case. Direct emission of fire $\mathrm{NO}_{\mathrm{x}}$ as PAN in the model is likely inadequate as the PAN can decompose back to $\mathrm{NO}_{\mathrm{x}}$ in the absence of supporting VOCs and with rapid dilution on the grid scale. A Lagrangian plume-in-grid approach may be needed, such as has been implemented in GEOS-Chem for ozone production in ship plumes (Vinken et al., 2011). In addition, absorption of UV radiation by the smoke would 

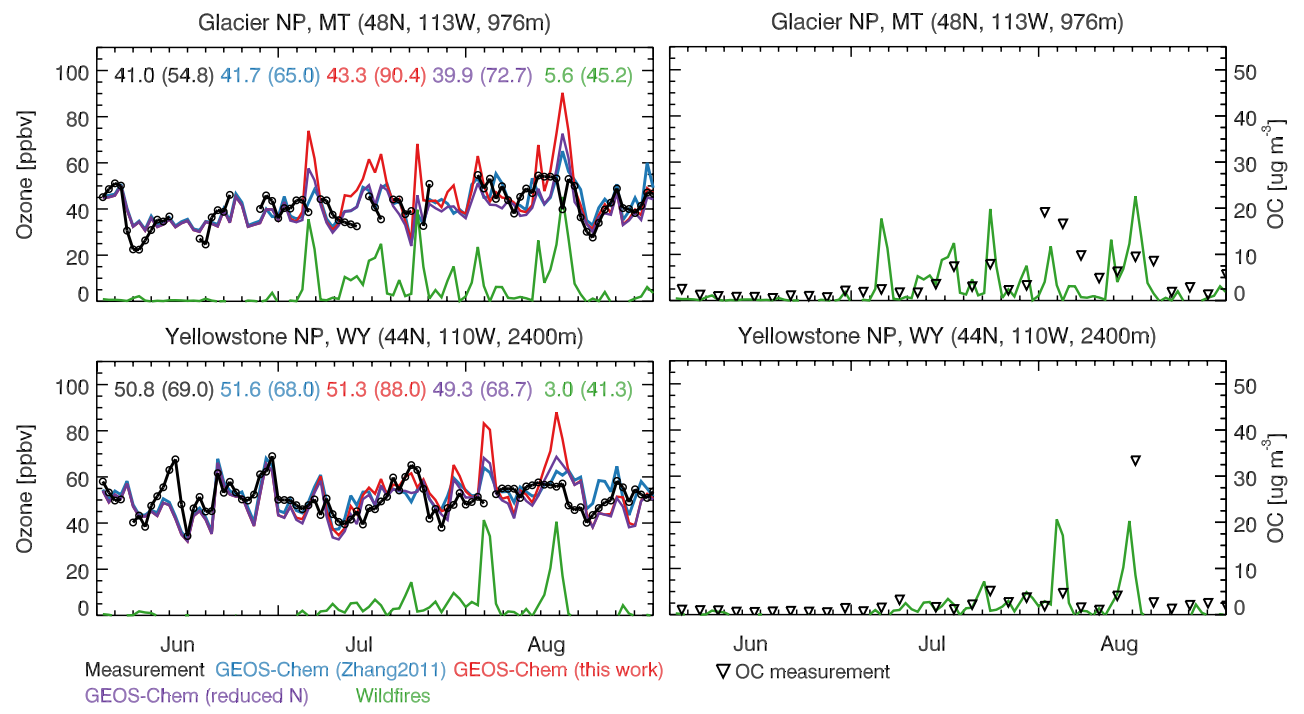

Figure 8. Time series of MDA8 ozone concentrations at the Glacier NP, Montana, and Yellowstone NP, Wyoming, CASTNet sites in summer 2007. Observations (black line) are compared to model results from Zhang et al. (2011) (blue line), model results from this work including daily emissions based on fire reports (red line), and further with reduced emission factor for $\mathrm{NO}_{\mathrm{x}}$ (purple line). Also shown are simulated wildfire ozone enhancements as computed by the difference between the improved simulation and a sensitivity simulation with wildfire emissions turned off (green line). The mean (maximum) concentrations for the time period are shown inset. Inverted triangles in the right panels are organic carbon (OC) particulate matter concentrations observed at collocated IMPROVE sites.

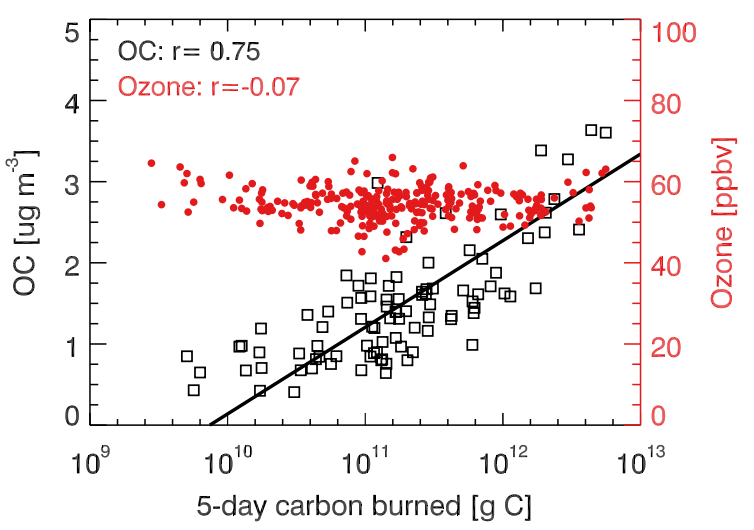

Figure 9. Relationship of organic carbon (OC) aerosol and ozone with wildfire carbon burned in the Intermountain West. Carbon burned is estimated for five-day periods in the summers 2006-2008 over the domain $\left(30-50^{\circ} \mathrm{N}, 120-100^{\circ} \mathrm{W}\right)$. OC aerosol and ozone concentrations are averages for IMPROVE (OC) and CASTNet (ozone) sites in the domain. The black line represents the reducedmajor-axis regression line of OC aerosol concentrations on wildfire carbon burned.

suppress ozone production. A regional model simulation by Jiang et al. (2012) suggests that light absorption by smoke could reduce ozone concentrations by up to $15 \%$ over fireinfluenced areas in the western US.

Jaffe et al. $(2008,2011)$ pointed to interannual correlation between summer mean surface ozone concentrations and wildfire areas burned in the Intermountain West as ev- idence for regional ozone enhancements from wildfires. We suggest that this observation could reflect common correlations with temperature rather than a causal relationship. Figure 10 shows the interannual correlations between summer mean MDA8 ozone concentrations, areas burned, and daytime (10:00-18:00 local time) surface air temperature averaged over the CASTNet sites in the Intermountain West for years 1990-2008. Both ozone and area burned correlate with temperature. Examination of model results at the ensemble of 11 elevated $(>1.5 \mathrm{~km})$ CASTNet sites for 2006-2008 in the Intermountain West also shows an ozone-temperature correlation consistent with observations (Fig. 10, bottom panel). The correlation in the model persists in the sensitivity simulation with wildfire emissions turned off. The summer mean ozone enhancements over the Intermountain West are thus not directly associated with wildfire emissions, consistent with Fig. 9 that shows no correlation on the daily timescale. We find that it is driven by planetary boundary layer (PBL) heights, which correlate strongly with temperature in the GEOS-5 data (Fig. 10, bottom panel). Higher surface temperature leads to a deeper PBL that allows free tropospheric air with higher ozone concentrations to mix down to the surface. As discussed above, the model may not capture the possible regional ozone enhancements from transport of PAN in fire plumes. Further observational evidence is needed to address the issue. 

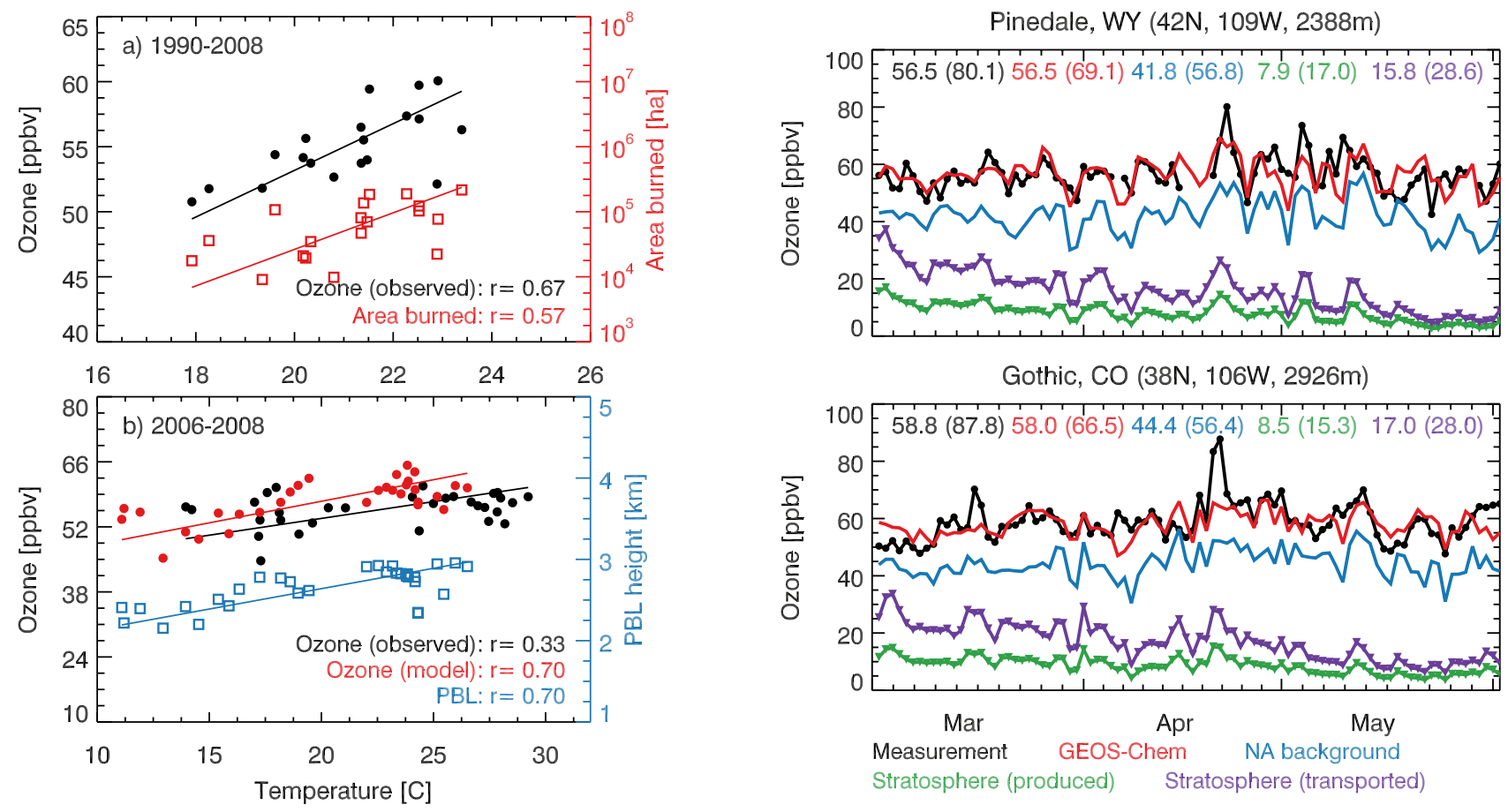

Figure 10. Relationships of MDA8 ozone, wildfire area burned, and daytime planetary boundary layer (PBL) height with surface air daytime temperature (10:00-18:00 local time) in the Intermountain West $\left(120-100^{\circ} \mathrm{W}, 31-49^{\circ} \mathrm{N}\right)$. MDA8 ozone is from the $11 \mathrm{CAST}$ Net sites in the Intermountain West (Fig. 3), wildfire area burned is from Yue et al. (2013) as described in the text, and PBL heights and temperatures are from the GEOS-5 data. The top panel shows interannual correlations averaged over the region for 1990-2008 in summer (June-August). The bottom panel shows spatial and interannual correlations for individual CASTNet sites for 2006-2008, with ozone from both the observations and the GEOS-Chem model. Correlation coefficients $(r)$ and reduced-major-axis regression lines are shown inset.

\subsection{Stratosphere}

Observations at high-elevation sites in the Intermountain West show that stratospheric intrusions can occasionally cause surface ozone concentrations to exceed the ozone NAAQS of 75 ppbv (Langford et al., 2009). Figure 11 shows time series of measured and simulated MDA8 ozone concentrations at Gothic, Colorado, and Pinedale, Wyoming, in spring 2006. A strong stratospheric intrusion occurred with measured ozone concentrations reaching $83-88 \mathrm{ppbv}$ on 19-20 April at Gothic and $81 \mathrm{ppbv}$ on 21 April at Pinedale. These were the highest ozone concentrations measured at the Intermountain West CASTNet sites in spring 2006-2008 (Fig. 5). The meteorological conditions driving this intrusion are described by Emery et al. (2012). GEOS-Chem shows a maximum in stratospheric influence during that event, as indicated by the tagged tracers (Fig. 11), but the magnitude is much less than observed. Emery et al. (2012) us-

Figure 11. Time series of MDA8 ozone concentrations at Pinedale, Wyoming, and Gothic, Colorado, in spring 2006. Model results (red line) are compared with measurements (black line). Also shown are the North American background (blue line), the stratospheric ozone contributions estimated as ozone produced in the stratosphere following Zhang et al. (2011) (green line), and those estimated as ozone transported across the tropopause following Lin et al. (2012) (purple line). The mean (maximum) values for the time period are shown inset.

ing the CAMx regional model with $12 \mathrm{~km}$ resolution and GEOS-Chem boundary conditions simulated concentrations 2-5 ppbv higher than GEOS-Chem during this event but still much lower than observed. As noted above, stretched-flow numerical diffusion greatly impairs the ability of Eulerian models to simulate fine-layered structures associated with stratospheric intrusions, and this problem is largely insensitive to changes in model grid resolution (Rastigejev et al., 2010).

We find however that it may be possible to correct for this predictable model bias. Figure 12 shows a positive correlation $(r=0.66)$ between the model bias on observed highozone days (> $70 \mathrm{ppbv}$ ) at CASTNet sites in the Intermountain West and the local stratospheric influence computed in the model as ozone produced in the stratosphere (standard GEOS-Chem method; green line in Fig. 11). The correlation is mainly driven by conditions when the stratospheric influence in the model exceeds $10 \mathrm{ppbv}$. In those cases, the regression line implies that the model underestimates stratospheric influence by a factor of 3 . Applying such a correction removes the bias, at least statistically. Under more typical conditions when observed ozone is higher than $60 \mathrm{ppbv}$, there 


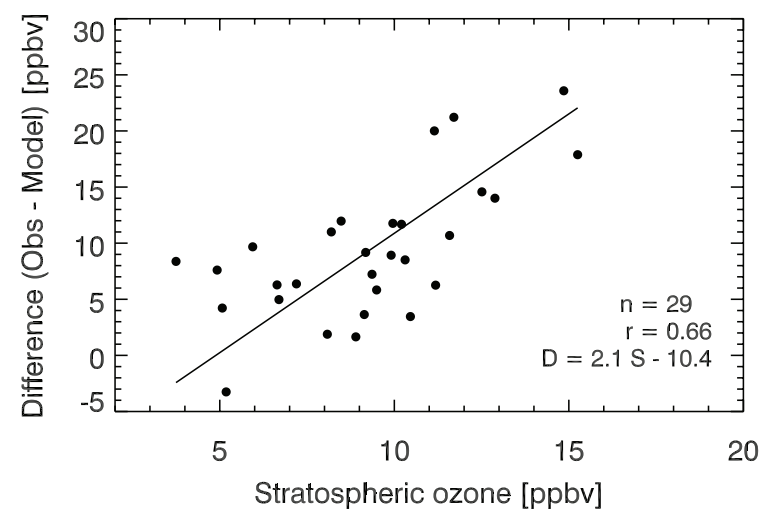

Figure 12. Predictability of model bias during high-ozone events (MDA8 ozone $>70 \mathrm{ppbv}$ ) at CASTNet sites in the Intermountain West in spring 2006. The figure shows a scatterplot of the GEOSChem low bias (observation minus model difference) vs. stratospheric ozone influence simulated by the model as ozone produced in the stratosphere. The black line shows the reduced-major-axis regression line. The number of occurrences, correlation coefficient, and the regression results are shown inset.

is no indication that the model bias is correlated with stratospheric influence. Thus the model bias associated with stratospheric intrusions does not imply an underestimate of stratospheric influence in the mean. The bias correction method proposed here could be used to better forecast high-ozone events of stratospheric origin or to quantify the stratospheric contribution to observed events.

Figure 11 shows time series for the stratospheric ozone tracers defined in two different ways, as described in Sect. 2.4. Stratospheric ozone defined as ozone produced in the stratosphere (standard GEOS-Chem definition) contributes $8.8-9.4 \mathrm{ppbv}$ at the two sites on average in spring, and shows peak values ( $\sim 15 \mathrm{ppbv}$ ) during the 19-21 April intrusion event. Stratospheric ozone defined as ozone transported from above the e90-tropopause (as used by Lin et al., 2012) is a factor of 2 higher with 16-17 ppbv on average and 21-27 ppbv for the intrusion event. The two measures of stratospheric influence are strongly correlated, as shown in Fig. 11. We find that using the GEOS-5 tropopause instead of the e90-tropopause has no effect on results. The difference between the two approaches suggests that half of the ozone transported from above the tropopause is actually produced in the troposphere.

Figure 7 shows the spatial distribution of seasonal mean stratospheric ozone influences in US surface air for spring 2006 estimated by the two different approaches. The patterns are very similar, with maximum stratospheric influence in the Intermountain West. Defining stratospheric ozone as ozone produced in the stratosphere (the standard GEOS-Chem definition) yields a seasonal mean stratospheric influence of 8 $10 \mathrm{ppbv}$ in the Intermountain West. Defining stratospheric ozone as ozone transported from above the tropopause (as in Lin et al., 2012) yields a mean influence of 12-18 ppbv.

Lin et al. (2012) reported a higher stratospheric influence in their AM3 model simulations, 2-3 times greater than GEOS-Chem estimates for the western US. We see from the above that about half of the difference reflects a difference in definition of stratospheric influence, not an actual physical difference. The remaining difference reflects the role of vertical transport that is more vigorous in AM3 (Fiore et al., 2014). The Lin et al. (2012) definition allows for anthropogenic ozone produced in the troposphere and then transported above the tropopause to be relabeled as stratospheric. The Lin et al. (2012) definition is well suited to quantifying the amount of ozone delivered to the surface by a stratospheric intrusion. It is not well suited for quantifying the influence on surface air from ozone produced naturally in the stratosphere. There the standard GEOS-Chem definition of stratospheric influence (ozone produced in the stratosphere) is the appropriate one to use.

\section{California pollution influence}

The Intermountain West is relatively remote and much of anthropogenic influence on ozone is expected to involve longrange transport. Estimates of intercontinental pollution and methane influence on ozone are generally consistent across global models (Fiore et al., 2009). Zhang et al. (2011) found that intercontinental pollution (anthropogenic $\mathrm{NO}_{\mathrm{x}}$ and nonmethane VOCs) and anthropogenic methane increased surface ozone in the Intermountain West by $13-16 \mathrm{ppbv}$ in spring and 11-13 ppbv in summer 2006, with intercontinental pollution alone accounting for $8-12 \mathrm{ppbv}$ in spring and 3-7 ppbv in summer. Anthropogenic emissions from Canada and Mexico added another 1-3 ppbv, similar to Wang et al. (2009). Here we examine the ozone enhancements from California anthropogenic emissions as a major source upwind of the Intermountain West (Langford et al., 2010).

Figure $7 \mathrm{e}$ shows the seasonal mean ozone enhancements from California anthropogenic emissions in surface air averaged for spring and summer 2006. Transport of ozone pollution from California increased the surface ozone concentrations in downwind areas of Nevada and Utah by 2$8 \mathrm{ppbv}$ in spring and 5-15 ppbv in summer. The two most affected CASTNet sites in the Intermountain West are Great Basin NP, Nevada, and Grand Canyon NP, Arizona, and we show the corresponding time series for March-August 2006 in Fig. 13. There is large temporal variability in California anthropogenic influence in the model, with events exceeding 20 ppbv. The Great Basin NP site has the largest influences, contributing 12-26 ppbv on the six days with observed MDA8 ozone $>70 \mathrm{ppbv}$ in spring-summer 2006. For the rest of the CASTNet sites in the Intermountain West, the California anthropogenic ozone influences are not correlated with 

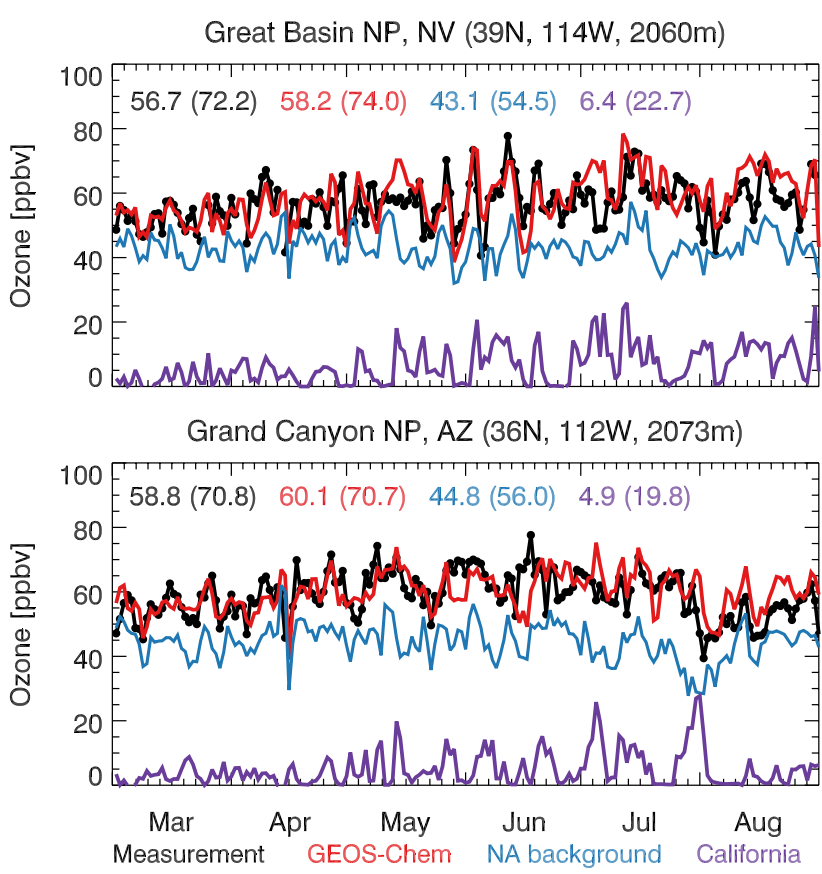

Figure 13. March-August time series of MDA8 ozone concentrations at Great Basin NP, Nevada, and Grand Canyon NP, Arizona, in 2006. Observations (black line) are compared to model results (red line). Also shown is the North American background (blue line), and ozone enhancements from California anthropogenic emissions (purple line) as determined from a sensitivity simulation with that source shut off. The mean concentrations for the time period and the annual fourth highest values are shown inset.

occurrences of highest ozone either in the model or in the observations.

\section{Conclusions}

We presented an analysis of the factors contributing to elevated background ozone in the US Intermountain West, using the GEOS-Chem CTM with $1 / 2^{\circ} \times 2 / 3^{\circ}$ horizontal resolution to interpret CASTNet ozone monitoring data for 2006-2008. Ozone concentrations in the region are relatively high, reflecting the elevated and arid terrain. Values are typically $40-60 \mathrm{ppbv}$ with frequent occurrences above $70 \mathrm{ppbv}$ and occasionally above $80 \mathrm{ppbv}$. This is an issue with regard to exceedance of the NAAQS, which is presently $75 \mathrm{ppbv}$ but could be tightened to $60-70 \mathrm{ppbv}$ in the future. Zhang et al. (2011) had previously applied GEOS-Chem to quantify the North American ozone background (defined as the concentration that would be present in the absence of North American anthropogenic emissions) across the US. They found the background to be highest in the Intermountain West. Here we examined the sources responsible for this elevated background and the ability of a model such as GEOSChem to represent them.
Major natural sources affecting background ozone in the Intermountain West include lightning, wildfires, and the stratosphere. Our work involved two major updates to the GEOS-Chem simulation of Zhang et al. (2011). We improved the model representation of lightning by using observational constraints from the NLDN. We also used a daily wildfire emission inventory for the western US compiled from fire reports. From a diagnostic perspective, we compared two alternate definitions for stratospheric influence on surface ozone: the standard GEOS-Chem approach (Zhang et al., 2011) where stratospheric ozone is defined as produced in the stratosphere, and the Lin et al. (2012) approach where stratospheric ozone is defined as transported from above the tropopause. The latter approach labels as "stratospheric" any ozone produced in the troposphere and then transported above the tropopause, and thus will diagnose a larger stratospheric influence.

We find that our improved lightning simulation largely corrects previous ozone overestimates by Zhang et al. (2011) over the southwest US in summer. We conclude that lightning enhances mean surface ozone in summer by about $10 \mathrm{ppbv}$ across the Intermountain West. Our work stresses the importance of using observational constraints for lightning in model simulations of background ozone, considering that standard convective parameterizations used in models fail to reproduce observed lightning distributions (Murray et al., 2012).

Wildfires are frequent occurrences in the western US in summer, and 2007 was a particularly high fire year. The daily wildfire emissions in GEOS-Chem generate highozone events in excess of $80 \mathrm{ppbv}$ over the fire burning areas, similar to the previous study of Mueller and Mallard (2011) using the CMAQ model. However, observations at CASTNet sites show no apparent ozone enhancements associated with fires. Regional ozone concentrations averaged across the Intermountain West show no correlation with wildfires, in contrast to OC aerosol observations from IMPROVE sites that show strong correlation. Models may overestimate the ozone production in fresh fire plumes due to inefficient conversion of fire $\mathrm{NO}_{\mathrm{x}}$ to PAN and dilution of the emissions on the grid scale. Although ozone enhancements are frequently observed in fire plumes and have potential to cause ozone exceedances in western metropolitan areas (Jaffe et al., 2013; Wigder et al., 2013), there is indication that this requires mixing of the fire plumes with urban pollution (Singh et al., 2010, 2012). More research is needed to understand ozone production from wildfires.

Previous studies have suggested that wildfires are a major source of ozone in the Intermountain West, pointing in particular to the interannual correlation between CASTNet surface ozone and wildfire occurrence (Jaffe et al., 2008; Jaffe, 2011). However, we find that this interannual correlation can be explained by common relationships with surface temperature. Higher surface temperatures lead to deeper PBL mixing entraining high ozone from the free troposphere. Wigder et 
al. (2013) and Jaffe et al. (2013) suggested that rapid conversion of $\mathrm{NO}_{\mathrm{x}}$ to PAN in fire plumes followed by regional-scale decomposition of PAN could lead to broad regional ozone enhancements in high fire years. Our results do not exclude this possibility. Improved understanding and model representation of PAN formation in fire plumes is needed to address the issue.

Stratospheric intrusions are responsible for the highest ozone concentrations observed at CASTNet sites in the Intermountain West in spring, including all occurrences of ozone above 75 ppbv. The GEOS-Chem model captures the timing of these stratospheric intrusions but the simulated magnitude is too weak. A previous CAMx model study with finer $12 \mathrm{~km}$ horizontal resolution performs only marginally better (Emery et al., 2012). This may reflect a general difficulty of Eulerian models in simulating the long-range transport of fine-layered structures, due to larger-than-expected numerical diffusion in a stretched-flow environment (Rastigeyev et al., 2010). We find however that the model bias is predictable, i.e., there is a relationship between the magnitude of model bias and the model-diagnosed stratospheric influence when ozone exceeds $70 \mathrm{ppbv}$. This relationship may be used to correct model simulations including forecast predictions if the stratospheric influence is tracked in the model.

Lin et al. (2012) using the AM3 model previously reported much larger stratospheric ozone influences over the Intermountain West than GEOS-Chem (Zhang et al., 2011), suggesting that GEOS-Chem underestimates stratospheric influence. However, the discrepancy largely reflects different definitions of stratospheric influence. Stratospheric influence is defined in GEOS-Chem (Zhang et al., 2011) as ozone produced in the stratosphere and transported to the troposphere. Lin et al. (2012) instead define stratospheric influence as ozone transported from above a chemically defined tropopause. We implemented the Lin et al. (2012) approach in GEOS-Chem and found that it doubles the diagnosed stratospheric influence. This is because it labels as "stratospheric" any ozone produced in the troposphere but transported temporarily above the tropopause. From the standpoint of diagnosing the amount of ozone associated with a stratospheric intrusion, the Lin et al. (2012) approach is appropriate. However, it is not appropriate to quantify the natural ozone background of stratospheric origin.

In this paper we did not revisit the influences of transboundary pollution on surface ozone in the US (Zhang et al., 2011), since these seem relatively consistent across models (Fiore et al., 2009). We examined the effect of California as a major anthropogenic source that might complicate interpretation of background surface ozone in the Intermountain West. We found that California anthropogenic emissions increase surface ozone concentrations in downwind areas of Nevada, Utah, and Arizona by $2-8 \mathrm{ppbv}$ in spring and 5-15 ppbv in summer 2006. There are frequent occurrences in these downwind states when California ozone enhance- ment exceeds $10 \mathrm{ppbv}$, but these are generally not associated with the highest ozone events.

Acknowledgements. This work was funded by BP America and by the NASA Air Quality Applied Science Team (AQAST). The NLDN data is provided by the NASA Lightning Imaging Sensor (LIS) instrument team and the NASA LIS Data Center via the NASA EOSDIS Global Hydrology Resource Center (GHRC) DAAC located at the Global Hydrology and Climate Center (GHCC), Huntsville, Alabama, through a license agreement with the Vaisala Group. The data available from the NASA EOSDIS GHRC DAAC are restricted to collaborators that have a working relationship with the NASA Marshall Space Flight Center (MSFC) Lightning Group.

Edited by: M. Kopacz

\section{References}

Akagi, S. K., Yokelson, R. J., Wiedinmyer, C., Alvarado, M. J., Reid, J. S., Karl, T., Crounse, J. D., and Wennberg, P. O.: Emission factors for open and domestic biomass burning for use in atmospheric models, Atmos. Chem. Phys., 11, 4039-4072, doi:10.5194/acp-11-4039-2011, 2011.

Alvarado, M. J., Logan, J. A., Mao, J., Apel, E., Riemer, D., Blake, D., Cohen, R. C., Min, K.-E., Perring, A. E., Browne, E. C., Wooldridge, P. J., Diskin, G. S., Sachse, G. W., Fuelberg, H., Sessions, W. R., Harrigan, D. L., Huey, G., Liao, J., Case-Hanks, A., Jimenez, J. L., Cubison, M. J., Vay, S. A., Weinheimer, A. J., Knapp, D. J., Montzka, D. D., Flocke, F. M., Pollack, I. B., Wennberg, P. O., Kurten, A., Crounse, J., Clair, J. M. St., Wisthaler, A., Mikoviny, T., Yantosca, R. M., Carouge, C. C., and Le Sager, P.: Nitrogen oxides and PAN in plumes from boreal fires during ARCTAS-B and their impact on ozone: an integrated analysis of aircraft and satellite observations, Atmos. Chem. Phys., 10, 9739-9760, doi:10.5194/acp-10-9739-2010, 2010.

Andreae, M. O. and Merlet, P.: Emission of trace gases and aerosols from biomass burning, Global Biogeochem. Cy., 15, 955-966, 2001.

Barrett, S. R. H., Yim, S. H. L., Gilmore, C. K., Murray, L. T., Kuhn, S. R., Tai, A. P. K., Yantosca, R. M., Byun, D. W., Ngan, F., Li, X., Levy, J. I., Ashok, A., Koo, J., Wong, H. M., Dessens, O., Balasubramanian, S., Fleming, G. G., Pearlson, M. N., Wollersheim, C., Malina, R., Arunachalam, S., Binkowski, F. S., Leibensperger, E. M., Jacob, D. J., Hileman, J. I., and Waitz, I. A.: Public Health, Climate, and Economic Impacts of Desulfurizing Jet Fuel, Environ. Sci. Technol., 46, 4275-4282, 2012.

Bertram, T. H., Perring, A. E., Wooldridge, P. J., Crounse, J. D., Kwan, A. J., Wennberg, P. O., Scheuer, E., Dibb, J., Avery, M., and Sachse, G.: Direct measurements of the convective recycling of the upper troposphere, Science, 315, 816-820, 2007.

Bey, I., Jacob, D. J., Yantosca, R. M., Logan, J. A., Field, B. D., Fiore, A. M., Li, Q., Liu, H., Mickley, L. J., and Schultz, M. G.: Global modeling of tropospheric chemistry with assimilated meteorology: Model description and evaluation, J. Geophys. Res., 106, 23073-23096, 2001.

Boccippio, D. J., Cummins, K. L., Christian, H. J., and Goodman, S. J.: Combined satellite-and surface-based estimation of 
the intracloud-cloud-to-ground lightning ratio over the continental United States, Mon. Weather Rev., 129, 108-122, 2001.

Chen, D., Wang, Y., McElroy, M. B., He, K., Yantosca, R. M., and Le Sager, P.: Regional CO pollution and export in China simulated by the high-resolution nested-grid GEOS-Chem model, Atmos. Chem. Phys., 9, 3825-3839, doi:10.5194/acp-9-3825-2009, 2009.

Cooper, O. R., Gao, R.-S., Tarasick, D., Leblanc, T., and Sweeney, C.: Long-term ozone trends at rural ozone monitoring sites across the United States, 1990-2010, J. Geophys. Res., 117, D22307, doi:10.1029/2012jd018261, 2012.

Emery, C., Jung, J., Downey, N., Johnson, J., Jimenez, M., Yarwood, G., and Morris, R.: Regional and global modeling estimates of policy relevant background ozone over the United States, Atmos. Environ., 47, 206-217, doi:10.1016/j.atmosenv.2011.11.012, 2012.

Fiore, A. M., Jacob, D. J., Bey, I., Yantosca, R. M., Field, B. D., and Fusco, A. C.: Background ozone over the United States in summer: Origin, trend, and contribution to pollution episodes, J. Geophys. Res., 107, doi:10.1029/2001JD000982, 2002.

Fiore, A., Jacob, D. J., Liu, H., Yantosca, R. M., Fairlie, T. D., and $\mathrm{Li}, \mathrm{Q}$. B.: Variability in surface ozone background over the United States: Implications for air quality policy, J. Geophys. Res., 108, 4787, doi:10.1029/2003jd003855, 2003.

Fiore, A. M., Dentener, F. J., Wild, O., Cuvelier, C., Schultz, M. G., Hess, P., Textor, C., Schulz, M., Doherty, R. M., Horowitz, L. W., MacKenzie, I. A., Sanderson, M. G., Shindell, D. T., Stevenson, D. S., Szopa, S., Van Dingenen, R., Zeng, G., Atherton, C., Bergmann, D., Bey, I., Carmichael, G., Collins, W. J., Duncan, B. N., Faluvegi, G., Folberth, G., Gauss, M., Gong, S., Hauglustaine, D., Holloway, T., Isaksen, I. S. A., Jacob, D. J., Jonson, J. E., Kaminski, J. W., Keating, T. J., Lupu, A., Marmer, E., Montanaro, V., Park, R. J., Pitari, G., Pringle, K. J., Pyle, J. A., Schroeder, S., Vivanco, M. G., Wind, P., Wojcik, G., Wu, S., and Zuber, A.: Multimodel estimates of intercontinental sourcereceptor relationships for ozone pollution, J. Geophys. Res., 114, D04301, doi:10.1029/2008jd010816, 2009.

Fiore, A. M., Oberman, J. T., Lin, M., Zhang, L., Clifton, O. E., Jacob, D. J., Naik, V., Horowitz, L. W., and Pinto, J. P.: Estimating North American background ozone in U.S. surface air with two independent global models: Variability, uncertainties, and recommendations, Atmos. Environ., in review, 2014.

Fischer, E. V., Jacob, D. J., Yantosca, R. M., Sulprizio, M. P., Millet, D. B., Mao, J., Paulot, F., Singh, H. B., Roiger, A., Ries, L., Talbot, R.W., Dzepina, K., and Pandey Deolal, S.: Atmospheric peroxyacetyl nitrate (PAN): a global budget and source attribution, Atmos. Chem. Phys., 14, 2679-2698, doi:10.5194/acp-142679-2014, 2014.

Horowitz, L. W., Liang, J., Gardner, G., and Jacob, D. J.: Export of reactive nitrogen from North America during summertime: Sensitivity to hydrocarbon chemistry, J. Geophys. Res., 103, 1345113476, 1998.

Hudman, R. C., Jacob, D. J., Turquety, S., Leibensperger, E. M., Murray, L. T., Wu, S., Gilliland, A. B., Avery, M., Bertram, T. H., Brune, W., Cohen, R. C., Dibb, J. E., Flocke, F. M., Fried, A., Holloway, J., Neuman, J. A., Orville, R., Perring, A., Ren, X., Sachse, G. W., Singh, H. B., Swanson, A., and Wooldridge, P. J.: Surface and lightning sources of nitrogen oxides over the United
States: Magnitudes, chemical evolution, and outflow, J. Geophys. Res., 112, D12S05, doi:10.1029/2006jd007912, 2007.

Huntrieser, H., Schlager, H., Roiger, A., Lichtenstern, M., Schumann, U., Kurz, C., Brunner, D., Schwierz, C., Richter, A., and Stohl, A.: Lightning-produced $\mathrm{NO}_{\mathrm{x}}$ over Brazil during TROCCINOX: airborne measurements in tropical and subtropical thunderstorms and the importance of mesoscale convective systems, Atmos. Chem. Phys., 7, 2987-3013, doi:10.5194/acp-7-29872007, 2007.

Huntrieser, H., Schumann, U., Schlager, H., Höller, H., Giez, A., Betz, H.-D., Brunner, D., Forster, C., Pinto Jr., O., and Calheiros, R.: Lightning activity in Brazilian thunderstorms during TROCCINOX: implications for $\mathrm{NO}_{\mathrm{x}}$ production, Atmos. Chem. Phys., 8, 921-953, doi:10.5194/acp-8-921-2008, 2008.

Jacob, D. J., Wofsy, S. C., Bakwin, P. S., Fan, S.-M., Harriss, R. C., Talbot, R. W., Bradshaw, J., Sandholm, S., Singh, H. B., Gregory, G. L., Browell, E. V., Sachse, G. W., Blake, D. R., and Fitzjarrald, D. R.: Summertime photochemistry at high northern latitudes, J. Geophys. Res., 97, 16421-16431, 1992.

Jaffe, D.: Relationship between surface and free tropospheric ozone in the Western U.S., Environ. Sci. Technol., 45, 432-438, 2011.

Jaffe, D., Chand, D., Hafner, W., Westerling, A., and Spracklen, D.: Influence of fires on $\mathrm{O}_{3}$ concentrations in the western US, Environ. Sci. Technol., 42, 5885-5891, doi:10.1021/es800084k, 2008.

Jaffe, D. A. and Wigder, N. L.: Ozone production from wildfires: A critical review, Atmos. Environ., 51, 1-10, 2012.

Jaffe, D. A., Wigder, N., Downey, N., Pfister, G., Boynard, A., and Reid, S. B.: Impact of wildfires on ozone exceptional events in the western US, Environ. Sci. Technol., 47, 11065-11072, 2013.

Jiang, X., Wiedinmyer, C., and Carlton, A. G.: Aerosols from Fires: An Examination of the Effects on Ozone Photochemistry in the Western United States, Environ. Sci. Technol., 46, 11878-11886, doi:10.1021/es301541k, 2012.

Kaynak, B., Hu, Y., Martin, R. V., Russell, A. G., Choi, Y., and Wang, Y.: The effect of lightning $\mathrm{NO}_{\mathrm{x}}$ production on surface ozone in the continental United States, Atmos. Chem. Phys., 8, 5151-5159, doi:10.5194/acp-8-5151-2008, 2008.

Langford, A. O., Aikin, K. C., Eubank, C. S., and Williams, E. J.: Stratospheric contribution to high surface ozone in Colorado during springtime, Geophys. Res. Lett., 36, L12801, doi:10.1029/2009g1038367, 2009.

Langford, A. O., Senff, C. J., Alvarez, R. J., Banta, R. M., and Hardesty, R. M.: Long-range transport of ozone from the Los Angeles Basin: A case study, Geophys. Res. Lett., 37, L06807, doi:10.1029/2010g1042507, 2010.

Li, Q., Jacob, D. J., Bey, I., Palmer, P. I., Duncan, B. N., Field, B. D., Martin, R. V., Fiore, A. M., Yantosca, R. M., and Parrish, D. D.: Transatlantic transport of pollution and its effects on surface ozone in Europe and North America, J. Geophys. Res., 107, doi:10.1029/2001JD001422, 2002.

Lin, M., Fiore, A. M., Cooper, O. R., Horowitz, L. W., Langford, A. O., Levy, H., Johnson, B. J., Naik, V., Oltmans, S. J., and Senff, C. J.: Springtime high surface ozone events over the western United States: Quantifying the role of stratospheric intrusions, J. Geophys. Res., 117, D00V22, doi:10.1029/2012jd018151, 2012.

Mao, J., Jacob, D. J., Evans, M. J., Olson, J. R., Ren, X., Brune, W. H., Clair, J. M. St., Crounse, J. D., Spencer, K. M., Beaver, M. R., Wennberg, P. O., Cubison, M. J., Jimenez, J. L., Fried, A., 
Weibring, P., Walega, J. G., Hall, S. R., Weinheimer, A. J., Cohen, R. C., Chen, G., Crawford, J. H., McNaughton, C., Clarke, A. D., Jaeglé, L., Fisher, J. A., Yantosca, R. M., Le Sager, P., and Carouge, C.: Chemistry of hydrogen oxide radicals $\left(\mathrm{HO}_{\mathrm{x}}\right)$ in the Arctic troposphere in spring, Atmos. Chem. Phys., 10, 58235838, doi:10.5194/acp-10-5823-2010, 2010.

Mauzerall, D. L., Logan, J. A., Jacob, D. J., Anderson, B. E., Blake, D. R., Bradshaw, J. D., Heikes, B., Sachse, G. W., Singh, H., and Talbot, B.: Photochemistry in biomass burning plumes and implications for tropospheric ozone over the tropical South Atlantic, J. Geophys. Res., 103, 8401-8423, 1998.

McDonald-Buller, E. C., Allen, D. T., Brown, N., Jacob, D. J., Jaffe, D., Kolb, C. E., Lefohn, A. S., Oltmans, S., Parrish, D. D., Yarwood, G., and Zhang, L.: Establishing Policy Relevant Background (PRB) Ozone Concentrations in the United States, Environ. Sci. Technol., 45, 9484-9497, doi:10.1021/es2022818, 2011.

McLinden, C. A., Olsen, S. C., Hannegan, B., Wild, O., Prather, M. J., and Sundet, J.: Stratospheric ozone in 3-D models: A simple chemistry and the cross-tropopause flux, J. Geophys. Res., 105, 14653-14665, 2000.

Mueller, S. F. and Mallard, J. W.: Contributions of Natural Emissions to Ozone and PM2.5as Simulated by the Community Multiscale Air Quality (CMAQ) Model, Environ. Sci. Technol., 45, 4817-4823, doi:10.1021/es103645m, 2011.

Murray, L. T., Jacob, D. J., Logan, J. A., Hudman, R. C., and Koshak, W. J.: Optimized regional and interannual variability of lightning in a global chemical transport model constrained by LIS/OTD satellite data, J. Geophys. Res., 117, D20307, doi:10.1029/2012jd017934, 2012.

Newell, R. E., Thouret, V., Cho, J. Y., Stoller, P., Marenco, A., and Smit, H. G.: Ubiquity of quasi-horizontal layers in the troposphere, Nature, 398, 316-319, 1999.

Ott, L. E., Pickering, K. E., Stenchikov, G. L., Allen, D. J., DeCaria, A. J., Ridley, B., Lin, R.-F., Lang, S., and Tao, W.-K.: Production of lightning $\mathrm{NO}_{\mathrm{x}}$ and its vertical distribution calculated from three-dimensional cloud-scale chemical transport model simulations, J. Geophys. Res., 115, D04301, doi:10.1029/2009jd011880, 2010.

Park, R. J., Jacob, D. J., and Logan, J. A.: Fire and biofuel contributions to annual mean aerosol mass concentrations in the United States, Atmos. Environ., 41, 7389-7400, 2007.

Prather, M. J., Zhu, X., Tang, Q., Hsu, J., and Neu, J. L.: An atmospheric chemist in search of the tropopause, J. Geophys. Res., 116, D04306, doi:10.1029/2010jd014939, 2011.

Rastigejev, Y., Park, R., Brenner, M. P., and Jacob, D. J.: Resolving intercontinental pollution plumes in global models of atmospheric transport, J. Geophys. Res., 115, D02302, doi:10.1029/2009jd012568, 2010.

Real, E., Law, K. S., Weinzierl, B., Fiebig, M., Petzold, A., Wild, O., Methven, J., Arnold, S., Stohl, A., Huntrieser, H., Roiger, A., Schlager, H., Stewart, D., Avery, M., Sachse, G., Browell, E., Ferrare, R., and Blake, D.: Processes influencing ozone levels in Alaskan forest fire plumes during long-range transport over the North Atlantic, J. Geophys. Res., 112, D10S41, doi:10.1029/2006jd007576, 2007.

Sauvage, B., Martin, R. V., van Donkelaar, A., Liu, X., Chance, K., Jaeglé, L., Palmer, P. I., Wu, S., and Fu, T.-M.: Remote sensed and in situ constraints on processes affecting trop- ical tropospheric ozone, Atmos. Chem. Phys., 7, 815-838, doi:10.5194/acp-7-815-2007, 2007.

Singh, H. B., Anderson, B. E., Brune, W. H., Cai, C., Cohen, R. C., Crawford, J. H., Cubison, M. J., Czech, E. P., Emmons, L., and Fuelberg, H. E.: Pollution influences on atmospheric composition and chemistry at high northern latitudes: Boreal and California forest fire emissions, Atmos. Environ., 44, 4553-4564, 2010.

Singh, H. B., Cai, C., Kaduwela, A., Weinheimer, A., and Wisthaler, A.: Interactions of fire emissions and urban pollution over California: Ozone formation and air quality simulations, Atmos. Environ., 56, 45-51, doi:10.1016/j.atmosenv.2012.03.046, 2012.

Smith, S. N. and Mueller, S. F.: Modeling natural emissions in the Community Multiscale Air Quality (CMAQ) Model-I: building an emissions data base, Atmos. Chem. Phys., 10, 4931-4952, doi:10.5194/acp-10-4931-2010, 2010.

Spracklen, D. V., Logan, J. A., Mickley, L. J., Park, R. J., Yevich, R., Westerling, A. L., and Jaffe, D. A.: Wildfires drive interannual variability of organic carbon aerosol in the western U.S. in summer, Geophys. Res. Lett., 34, L16816, doi:10.1029/2007g1030037, 2007.

Sudo, K. and Akimoto, H.: Global source attribution of tropospheric ozone: Long-range transport from various source regions, J. Geophys. Res., 112, D12302, doi:10.1029/2006jd007992, 2007.

Thompson, A. M., Stone, J. B., Witte, J. C., Miller, S. K., Oltmans, S. J., Kucsera, T. L., Ross, K. L., Pickering, K. E., Merrill, J. T., Forbes, G., Tarasick, D. W., Joseph, E., Schmidlin, F. J., McMillan, W. W., Warner, J., Hintsa, E. J., and Johnson, J. E.: Intercontinental Chemical Transport Experiment Ozonesonde Network Study (IONS) 2004: 2. Tropospheric ozone budgets and variability over northeastern North America, J. Geophys. Res., 112, D12S13, doi:10.1029/2006jd007670, 2007.

Thompson, A. M., Yorks, J. E., Miller, S. K., Witte, J. C., Dougherty, K. M., Morris, G. A., Baumgardner, D., Ladino, L., and Rappenglück, B.: Tropospheric ozone sources and wave activity over Mexico City and Houston during MILAGRO/Intercontinental Transport Experiment (INTEX-B) Ozonesonde Network Study, 2006 (IONS-06), Atmos. Chem. Phys., 8, 5113-5125, doi:10.5194/acp-8-5113-2008, 2008.

US Environmental Protection Agency, Air Quality Criteria for Ozone and Related Photochemical Oxidants (Final), Vols. I, II, and III, EPA 600/R-05/004aF-cF, 2006.

US Environmental Protection Agency, National ambient air quality standards for ozone, Fed. Regist., 75, 2938-3052, 2010.

van der Werf, G. R., Randerson, J. T., Giglio, L., Collatz, G. J., Mu, M., Kasibhatla, P. S., Morton, D. C., DeFries, R. S., Jin, Y., and van Leeuwen, T. T.: Global fire emissions and the contribution of deforestation, savanna, forest, agricultural, and peat fires (19972009), Atmos. Chem. Phys., 10, 11707-11735, doi:10.5194/acp10-11707-2010, 2010.

Vinken, G. C. M., Boersma, K. F., Jacob, D. J., and Meijer, E. W.: Accounting for non-linear chemistry of ship plumes in the GEOS-Chem global chemistry transport model, Atmos. Chem. Phys., 11, 11707-11722, doi:10.5194/acp-11-11707-2011, 2011.

Wang, Y. H., Jacob, D. J., and Logan, J. A.: Global simulation of tropospheric $\mathrm{O}_{3}-\mathrm{NO}_{\mathrm{x}}$-hydrocarbon chemistry, 3. Origins of tropospheric ozone and effects of nonmethance hydrocarbons, J. Geophys. Res., 103, 10757-10767, 1998.

Wang, H., Jacob, D., Lesager, P., Streets, D., Park, R., Gilliland, A., and Van donkelaar, A.: Surface ozone background in the United 
States: Canadian and Mexican pollution influences, Atmos. Environ., 43, 1310-1319, 2009.

Westerling, A. L., Hidalgo, H. G., Cayan, D. R., and Swetnam, T. W.: Warming and earlier spring increase western U.S. forest wildfire activity, Science, 313, 940-943, 2006.

Wigder, N. L., Jaffe, D. A., and Saketa, F. A.: Ozone and particulate matter enhancements from regional wildfires observed at Mount Bachelor during 2004-2011, Atmos. Environ., 75, 24-31, doi:10.1016/j.atmosenv.2013.04.026, 2013.

Yue, X., Mickley, L. J., Logan, J. A., and Kaplan, J. O.: Ensemble projections of wildfire activity and carbonaceous aerosol concentrations over the western United States in the mid-21st century, Atmos. Environ., 77, 767-780, 2013.

Zhang, L., Jacob, D. J., Kopacz, M., Henze, D. K., Singh, K., and Jaffe, D. A.: Intercontinental source attribution of ozone pollution at western U.S. sites using an adjoint method, Geophys. Res. Lett., 36, L11810, doi:10.1029/2009gl037950, 2009.
Zhang, L., Jacob, D. J., Liu, X., Logan, J. A., Chance, K., Eldering, A., and Bojkov, B. R.: Intercomparison methods for satellite measurements of atmospheric composition: application to tropospheric ozone from TES and OMI, Atmos. Chem. Phys., 10, 4725-4739, doi:10.5194/acp-10-4725-2010, 2010.

Zhang, L., Jacob, D. J., Downey, N. V., Wood, D. A., Blewitt, D., Carouge, C. C., van Donkelaar, A., Jones, D. B. A., Murray, L. T., and Wang, Y.: Improved estimate of the policy-relevant background ozone in the United States using the GEOS-Chem global model with $1 / 2^{\circ} \times 2 / 3^{\circ}$ horizontal resolution over North America, Atmos. Environ., 45, 6769-6776, doi:10.1016/j.atmosenv.2011.07.054, 2011."

Zhang, L., Jacob, D. J., Knipping, E. M., Kumar, N., Munger, J. W., Carouge, C. C., van Donkelaar, A., Wang, Y. X., and Chen, D.: Nitrogen deposition to the United States: distribution, sources, and processes, Atmos. Chem. Phys., 12, 4539-4554, doi:10.5194/acp-12-4539-2012, 2012. 